\title{
Pelatihan Membuat Konten Promosi di Media Sosial bagi UMKM Mitra Masjid
}

\author{
Sri Mustika ${ }^{*}$, Andys Tiara1, dan Tellys Corliana ${ }^{1}$ \\ ${ }^{I}$ Program Studi Ilmu Komunikasi, Fakultas Ilmu Sosial dan Ilmu Politik, Universtitas Muhammadiyah \\ Prof. Dr. HAMKA (UHAMKA), Jl. Limau II No.3, Kramat Pela, Kebayoran Baru, Jakarta Selatan \\ Email Penulis Korespondensi: srimustika@uhamka.ac.id
}

\begin{abstract}
The Covid-19 pandemic in Indonesia has an impact not only on health problems but also on economic and social issues. The Large-Scale Social Restrictions (PSBB) Policy to push the rate of Covid-19 transmission also reduces the rate of economic development. The Small and Medium Enterprise (SME) partners of the Al Ikhlash mosque, Jati Padang, South Jakarta are affected too. Trading opportunities around the mosque no longer exist, so they run into a decrease in income. One way to maintain business continuity is by utilizing digital media. Unfortunately, they are still unfamiliar with digital media. PKM FISIP UHAMKA team tried to participate in offer solutions to SME problems by providing counseling on the basics of entrepreneurship, market, social media introduction, promotional content on social media, and the practice of creating promotional content through an online platform. This training is intended to familiarize participants with social media to increase the insight, knowledge, and MSMEs Mosque Partners' skill in overcoming this obstacle they face during the Covid-19 pandemic. Following and adjust the health protocol rules, the training went well. As a result, through this training in creating promotional content on social media, participants' understanding of the importance of online promotion increased. That's not all, one of the obstacles faced by MSMEs partners of Masjid Al Ikhlash Jati Padang about their lack of entrepreneurial strength can be overcome with an entrepreneurial spirit. Moreover, takes courage to innovate, creativity, persistence, a strong competitive mentality, and good digital use skill needed too. Therefore, these kinds of training need to be held regularly, so the MSMEs Mosque Partners can compete in the digital era.
\end{abstract}

Keywords: Covid-19, Promotion Content, SME, Social Media.

\begin{abstract}
Abstrak
Pandemi Covid-19 di Indonesia berdampak tidak saja pada masalah kesehatan, tetapi juga ekonomi dan sosial. Kebijakan Pembatasan Sosial Berskala Besar (PSBB) untuk menekan laju penularan Covid19 ikut menekan laju perkembangan ekonomi. UMKM mitra masjid Al Ikhlash, Jati Padang, Jakarta Selatan tidak terkecuali ikut terdampak. Peluang berdagang di seputar masjid tidak ada lagi, sehingga mereka mengalami penurunan pemasukan. Salah satu cara untuk mempertahankan keberlangsungan usaha adalah dengan memanfaatkan media digital. Sayangnya, mereka masih asing dengan media digital. Tim PKM FISIP UHAMKA berusaha untuk turut serta memberikan solusi bagi permasalahan UMKM dengan memberikan penyuluhan mengenai dasar-dasar kewirausahaan, mengenal target pasar, pengenalan media sosial, konten-konten promosi di media sosial dan praktik pembuatan konten promosi melalui salah satu platform online. Pelatihan ini dimaksudkan untuk mengakrabkan peserta dengan media sosial guna meningkatkan wawasan, pengetahuan, dan keterampilan UMKM Mitra Masjid dalam memasarkan produknya. Pelatihan yang dilaksanakan dengan mengikuti protokol kesehatan ini berjalan dengan baik. Hasilnya, pemahaman peserta mengenai media sosial dan pentingnya berpromosi secara daring meningkat. Selain itu, para pelaku UMKM mitra Masjid Al Ikhlash Jati Padang yang semula masih kurang semangat kewirausahaannya melalui pelatihan ini meningkat. Mereka perlu terus didorong untuk berinovasi, berpikir dan bertindak kreatif, berani bersaing, dan memiliki keterampilan menggunakan media digital. Pelatihan-pelatihan semacam ini perlu diadakan secara rutin, agar para pelaku UMKM mitra masjid mampu bersaing pada era digital.
\end{abstract}

\section{Kata Kunci: Covid-19, Konten Promosi, UMKM, Media Sosial}




\section{PENDAHULUAN}

Usaha Mikro, Kecil dan Menengah (UMKM) tergolong kelompok usaha yang memiliki daya tahan tinggi terhadap berbagai macam krisis. Pada masa krisis moneter 1998 dan krisis ekonomi global 2008, UMKM tidak terlalu signifikan terkena dampaknya. Bahkan krisis global 2008 menjadi momentum bagi UMKM untuk berada di garda terdepan dalam membangun ekonomi rakyat. Melihat kontribusinya pada perekonomian nasional yang semakin signifikan dalam menghasilkan output positif dan memacu pertumbuhan ekonomi Indonesia, sudah sepatutnya UMKM mendapat perhatian penuh, terutama pada masa pandemi Covid-19 yang menyebar di Indonesia sejak 2 Maret 2020.

Berbeda dengan situasi krisis sebelumnya, pandemi Covid-19 ternyata memukul keberadaan UMKM, termasuk UMKM di DKI Jakarta yang wilayahnya paling banyak terkena kasus Covid-19. Wilayah Jakarta Selatan sempat menjadi zona merah, karena banyak kelurahan yang warganya tertular Covid-19. (www.kompas.com, 06 Juni 2020)

Berbagai penerapan kebijakan seperti work from home, learn from home, dan pray from home serta physical distancing atau Pembatasan Sosial Berskala Besar (PSBB) dilakukan guna untuk menekan laju pertumbuhan pandemi Covid-19. Kebijakan ini sangat tepat dilakukan, namun membawa dampak pada sektor usaha, termasuk UMKM.

UMKM mitra masjid Al Ikhlash Jati Padang, Jakarta Selatan sangat merasakan dampak ekonomi akibat kebijakan PSBB, baik pada periode awal pada Maret 2020 maupun periode kedua pada September 2020. Ketika masjid ditutup sementara, mereka yang biasanya berdagang di sekitar masjid tidak bisa lagi berjualan. Kelompok usaha ini pun produksinya terganggu, sehingga pemasukannya menurun dratis, bahkan ada yang sampai gulung tikar.

Munculnya kebijakan PSBB mendorong perubahan dalam perdagangan. Jika semula dilakukan secara langsung, kini beralih ke edagang. Keberadaan ekonomi digital ditandai dengan semakin maraknya bisnis melalui Internet sebagai medium komunikasi, kolaborasi, dan kooperasi antara perusahaan ataupun individu (Wirabrata, 2016). Proses komunikasi, kolaborasi, ataupun korporasi dapat dilakukan dengan siapa saja. Keterbukaan ini memunculkan berbagai varian bisnis dan membuat persaingan usaha menjadi ketat.

Kondisi baru ini mendorong UMKM untuk mengikuti perkembangan. UMKM mau tidak mau harus bermigrasi ke e-dagang dengan memanfaatkan media digital guna mempromosikan produk atau jasanya sekaligus untuk bertransaksi. Dengan memanfaatkan media digital, UMKM dapat membidik target pasarnya secara lebih luas. Banyak UMKM yang berhasil bertahan setelah berpromosi melalui media digital.

Kendati demikian, sebagian UMKM $(60 \%)$ masih terkendala, karena mereka belum melek digital dan tingkat literasi teknologinya rendah. Padahal saat ini hampir semua informasi dibagikan melalui media digital. Misalnya, informasi mengenai pelatihan-pelatihan bagi UMKM secara gratis oleh pemerintah atau lembaga swasta. Dengan mengikuti pelatihanpelatihan tersebut diharapkan UMKM dapat meningkatkan kapasitasnya, agar dapat bertahan menghadapi situasi yang tidak menentu seperti sekarang.

UMKM mitra Masjid Al Ikhlash termasuk pelaku UMKM yang belum melek digital. Kebanyakan dari mereka menggunakan telepon pintar sebatas untuk mengirim dan menerima pesan WA atau menelepon. Belum banyak mitra yang memanfaatkan telepon pintarnya untuk mempromosikan produk atau jasanya. Mereka juga belum banyak mengikuti pelatihanpelatihan kewirausahaan, mulai dari tingkat dasar hingga mahir. Karena itu mereka belum banyak mengetahui pemanfaatan media digital sebagai sarana promosi.

Pelatihan ini bertujuan untuk mengedukasi para UMKM mitra Masjid tentang pembuatan konten promosi melalui media sosial. Dengan pelatihan ini diharapkan pengetahuan mitra tentang media digital meningkat. Demikian pula keterampilannya dalam membuat konten media sosial, khususnya untuk mempromosikan produknya.

\section{METODE}

Dalam kegiatan ini, tim menggunakan metode dalam pendidikan masyarakat, seperti: a). Pelatihan, dan b). Penyuluhan, yang bertujuan untuk meningkatkan pemahaman dan kesadaran mitra. Jadi, selain memberikan sosialisasi, tim juga memberikan pelatihan. Pelatihan yang diberikan meliputi praktik membuat konten promosi di media sosial 
dengan menggunakan salah satu platform online. Sementara untuk penyuluhan, Tim memberikan pengetahuan dan pemahaman berupa materi-materi yang sesuai dengan permasalahan UMKM.

Dengan pelatihan ini, peserta diasumsikan akan mengalami penambahan pengetahuan, khususnya tentang dasar-dasar kewirausahaan, target konsumen, dan konten promosi di media sosial.

\section{Waktu dan Tempat Pelaksanaan}

Kegiatan pengabdian bertajuk Pelatihan Pembuatan Konten Promosi untuk Media Sosial bagi UMKM Mitra Masjid ini dilaksanakan di Masjid Al-Ikhlas Jati Padang, Jalan Raya Ragunan No.11A, Kelurahan Jati Padang, Pasar Minggu, Jakarta Selatan. Kegiatan ini diikuti 15 peserta dan dilakukan dengan mengikuti aturan protokol kesehatan. Kegiatan diberikan pada 12 Desember 2020 dari pukul 08.00-12.00 dan setelah itu para peserta diberikan kesempatan untuk berkonsultasi dengan tim melalui Whatts app hingga dua minggu kemudian.

\section{Langkah Pelaksanaan}

Pelatihan ditindaklanjuti dengan praktik pembuatan konten promosi melalui salah satu platform desain daring gratis. Penyuluhan dilakukan dengan memberikan pengetahuan dan pemahaman mengenai dasar-dasar kewirausahaan dan cara mempromosikan produk atau jasa. Tim pengabdian masyarakat menawarkan solusi dengan memberikan:
1. Pengetahuan
mengenai
dasar-dasar kewirausahaan.

2. Pengetahuan mengenai target pasar(konsumen).

3. Pengenalan mengenai media digital dan jenisjenis konten promosi di media sosial.

4. Praktik tentang pembuatan konten promosi di media sosial.

\section{HASIL DAN PEMBAHASAN}

Pelatihan Pembuatan Konten Promosi untuk Media Sosial bagi UMKM Mitra Masjid dipilih sebagai topik kegiatan ini, karena kelompok UMKM ini mengalami dampak Covid-19 yang berat. Sebelum Covid-19 mereka dapat berjualan di sekitar masjid, namun setelah pandemi terpaksa dihentikan. Hal ini membatasi produksi dan mengurangi penghasilan mereka.
Selain itu, kebijakan PSBB telah mengubah kebiasaan masyarakat dalam memenuhi kebutuhan hidupnya dengan menggunakan media digital. Mereka juga telah mengubah secara fundamental berbagai bentuk aktivitas ekonominya. Keberadaan ekonomi digital ini ditandai dengan maraknya transaksi perdagangan melalui Internet (e-dagang) sebagai medium komunikasi, kolaborasi, dan kooperasi antara perusahaan ataupun individu (Wirabrata, 2016).

Dampak dari kebiasaan masyarakat bertransaksi melalui media daring ini adalah munculnya berbagai macam varian dan kegiatan bisnis melalui media digital, sehingga memperketat persaingan usaha para UMKM.

Hadiwinata, Mundzir, dan Muslim (2020) mengungkapkan "Beruntunglah kita hidup di dunia serba maju. Salah satu penolong kita adalah Internet. Teknologi Internet menjadi penolong utama dalam pemasaran produk. Salah satunya ialah dengan kehadiran media sosial."

Dalam kondisi pandemi, beragam aktivitas dilakukan dengan memanfaatkan platform online. Salah satunya ialah media sosial. Penggunaan media sosial secara signifikan sebagai alat komunikasi tidak hanya berlaku untuk pribadi, keluarga, pertemanan ataupun pergaulan, tetapi juga dapat untuk melakukan komunikasi bisnis bagi UMKM.

Berdasarkan hasil observasi selama pelatihan dan penyuluhan, tim menemukan hambatan utama UMKM mitra masjid dalam menghadapi situasi baru adalah:

\section{Jiwa Kewirausahaan}

Dalam menjalankan usahanya masih ada mitra yang belum percaya diri, karena berpikir bahwa berwirausaha kurang memiliki prestise. Pelaku UMKM dari kalangan terdidik beranggapan bekerja di kantor lebih pasti dan rate of returnnya sebanding dengan tenaga yang dikeluarkan. Pola pikir demikian membuat mereka kurang optimistis, kurang berani bermimpi untuk berkembang, dan kurang berani mengeksplorasi kreativitasnya untuk mempromosikan produk dan jasanya.

\section{Penguasaan Teknologi UMKM}

Kebijakan pemerintah agar masyarakat bekerja dari rumah mendorong penggunaan media sosial meningkat tajam. Banyak konsumen yang beralih berbelanja secara daring. Kehadiran 
berbagai macam varian bisnis pun merambah ke media digital. Sayangnya, dalam menghadapi perubahan ini mitra UMKM belum terlalu siap. Hasil wawancara dengan mitra UMKM menemukan data sebagai berikut:

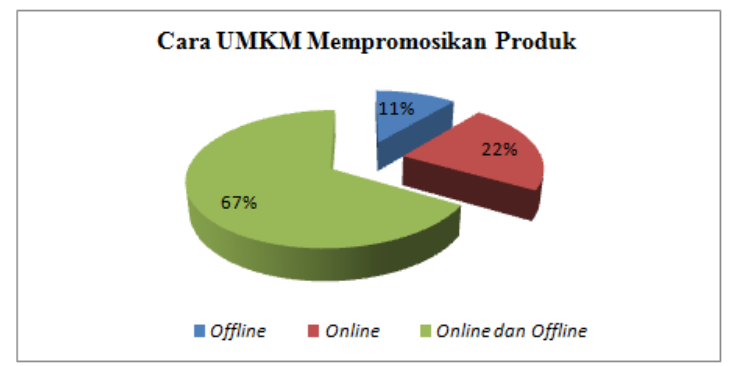

Gambar 1. Cara UMKM Mempromosikan Produk

Dari gambar di atas tampak bahwa sejumlah $67 \%$ UMKM menggunakan dua metode promosi sekaligus, daring dan luring. Hanya 22\% UMKM yang menggunakan satu cara, yaitu menggunakan media sosial. Sisanya, $11 \%$ UMKM masih memilih luring. Mereka mempromosikan produknya secara luring dari mulut ke mulut (word of mouth) yang disampaikan kepada sanak keluarga, para tetangga, dan teman-teman. Ada kalanya juga dengan mengikuti bazaar sesuai protokol kesehatan atau menitipkan barang dagangannya di warung yang dikenal atau di toko-toko dan kantin terdekat.

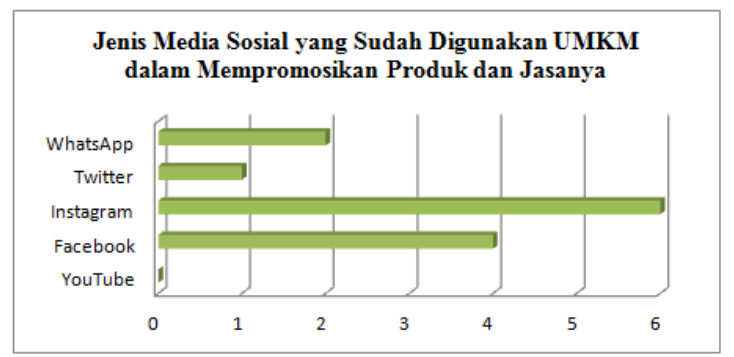

Gambar 2. Jenis Media Sosial yang Sudah Digunakan UMKM

Para UMKM yang berpromosi di media sosial paling banyak memilih Instagram, kemudian Facebook, WhatsApp Stories, dan Twitter. Mereka belum pernah menggunakan media sosial YouTube untuk berpromosi.

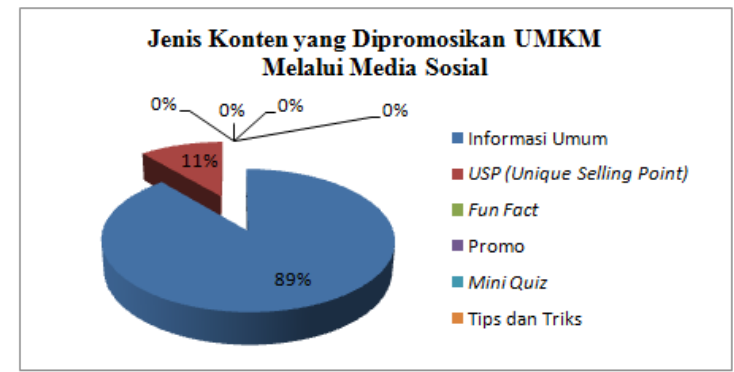

Gambar 3. Jenis Konten yang Dipromosikan UMKM melalui Media Sosial

Dalam menggunakan media sosial mitra masih menginformasikan hal-hal yang umum menyangkut produk atau jasa dan harganya. Sebagian kecil (11\%) UMKM memberikan informasi Unique Selling Point (USP) berupa kelebihan produk atau jasanya, Fun Fact atau fakta-fakta menyenangkan tentang produk atau jasanya, promosi, dan Mini Quiz serta Tips dan Triks yang dapat menggiring konsumen untuk memilih produk atau jasa mereka. Kekhususan atau keunikan seperti ini oleh UMKM yang lain tidak diinfokan pada konsumen. Padahal hal-hal seperti inilah yang justru dapat mendorong konsumen mencoba produk atau jasa para UMKM mitra.

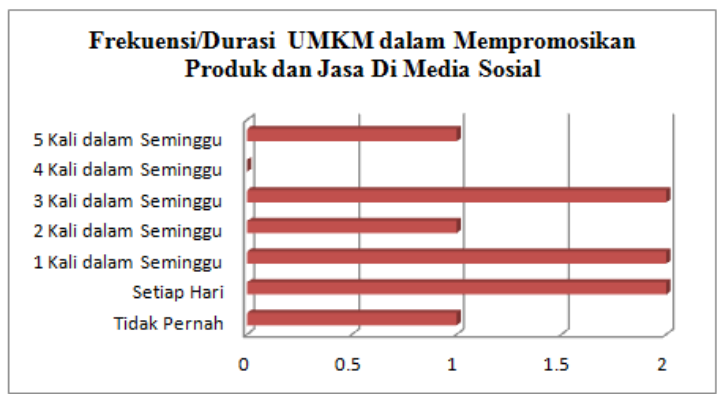

Gambar 4. Durasi UMKM dalam Mempromosikan/ Memposting di Media Sosial

UMKM mitra mengunggah promosi produk atau jasanya di media sosial yang paling banyak 1 sampai dengan 3 kali dalam seminggu. Setiap kali mengunggah ada beberapa postingan. Kendati demikian sebagian besar UMKM hampir tidak pernah memposting produk atau jasanya. Meskipun ada yang memposting 5 kali dalam satu minggu. 
Pemahaman UMKM terhadap manfaat berpromosi di media sosial sangat minim. Padahal promosi semacam ini dapat menjangkau sasaran lebih luas, sehingga mereka dapat menemukan lebih banyak konsumen dan lebih efektif.

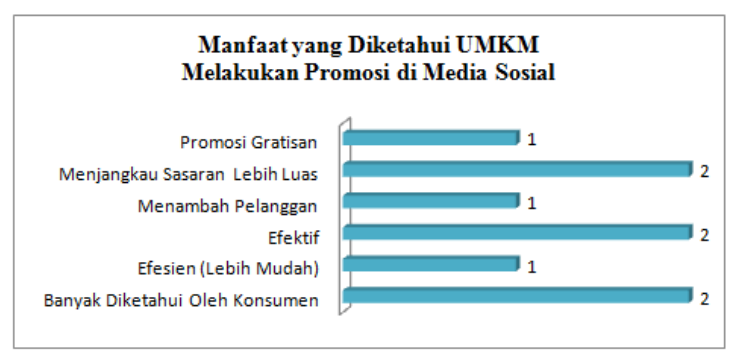

Gambar 5. Pengetahuan UMKM tentang Manfaat Berpromosi di Media Sosial

\section{Pelatihan Pembuatan Konten Promosi di Media Sosial bagi UMKM}

UMKM dapat memilih mempromosikan produk atau jasanya melalui media sosial demi mempertahankan tumbuh kembang dan keberlangsungan usahanya pada era digital, khususnya pada saat pandemi Covid-19. Untuk itu tim melatih peserta membuat konten promosi di media sosial.

Pelatihan ini bertujuan memotivasi dan mengedukasi mitra tentang dasar-dasar kewirausahaan, cara-cara mempromosikan produk/jasa, jenis dan bentuk konten promosi, serta pemilihan waktu untuk mengunggah konten di media sosial. Materi dasar-dasar kewirusahaan diberikan, karena para peserta masih tergolong baru dalam berwirausaha. Salah satu hambatan yang mereka hadapi adalah rendahnya semangat dan kepercayaan diri dalam berusaha, karena mereka termakan pandangan negatif masyarakat terhadap profesi pengusaha.

Peserta juga mendapatkan pengetahuan tentang teknik pembuatan konten promosi melalui satu satu platform desain daring gratis, Canva. Materi ini diharapkan membuat mereka memahami kiat-kiat berpromosi di media sosial sekaligus cara membuat kontennya.

"Kami suka kurang pede menawarkan dagangan. Soalnya, banyak orang menyepelekan dagangan yang kami tawarkan," ungkap Ibu Kiki yang usahanya membuat kuekue.

Untuk menyemangati peserta yang belum percaya diri, Dra. Tellys Corliana, M. Hum, salah satu pemateri yang juga Dekan FISIP Universitas Muhammadiyah Prof. Dr. HAMKA menegaskan, "Wirausaha berasal dari kata wira.
Artinya, pejuang, pahlawan, manusia unggul, berjiwa besar, teladan dan berwatak agung. Jadi, wirausahawan adalah pejuang atau pahlawan. Mereka berdiri di atas kaki sendiri. Memiliki hak penuh atas diri dan pemikirannya. Berjiwa bebas dalam berkreasi. Wirausahawan adalah seorang pemimpin. Jadi, tidak perlu minder berwirausaha."

Meskipun sudah ada sebagian UMKM yang berpromosi secara daring, namun masih ada di antara mereka yang belum memahami cara berpromosi di media sosial untuk mendapatkan hasil yang baik. Mereka beranggapan dengan mengunggah produk/jasanya setiap hari di media daring dampaknya akan langsung. Padahal tidak demikian. Dalam mengunggah ada waktu-waktu tertentu yang tepat sesuai jenis media sosialnya. Pesan-pesan yang diunggah juga tidak sekadar berbunyi, dijual murah atau ada diskon, melainkan harus disajikan dengan kata-kata yang menarik. Postingan hendaknya juga tidak seragam. Baik tampilan visual maupun kata-katanya harus bervariasi.

Untuk itu tim menekankan agar para mitra memahami beragam bentuk dan jenis konten promosi di media sosial. Juga mengenai pemilihan waktu yang tepat untuk mengunggah konten promosi, termasuk penjadwalan untuk hal-hal yang unik tentang produk/jasa mereka.

Tim menunjukkan lima media sosial yang banyak digunakan di Indonesia berdasarkan data dari Hootsuite (We are Social) pada Januari 2020, yaitu: YouTube, WhatsApp, Facebook, Instagram, Twitter dan Line. Selain itu, tim memberikan tips dan trik mempromosikan usaha di media sosial. Faktanya masih banyak orang memiliki akun di sosial media, tetapi tidak tahu materi apa yang akan diunggah, kapan dan jam berapa mengunggah, apa saja yang harus dipersiapkan dan harus dilakukan sebelum mengunggah. Tim juga memperkenalkan beberapa jenis konten promosi yang dapat dibuat dan diunggah di media sosial, di antaranya:

1. Informasi Umum Suatu Produk. Menampilkan informasi umum atau gambaran sebuah produk atau jasa menyangkut apa yang ditawarkan, lokasi, cara pembuatan produk, bahan-bahan yang digunakan dan cara membeli atau menggunakan produk atau jasa.

2. USP (Unique Selling Point). Sebuah unggahan tentang keunikan produk atau jasa, ciri khasnya yang membedakan dengan produk lain. 
3. Fun Fact. Fakta-Fakta yang menyenangkan tentang produk atau jasa. Fakta ini dapat menarik minat konsumen untuk mencoba produk UMKM.

4. Promo-Promo. Informasi tentang promopromo produk atau jasa UMKM sangat digemari konsumen. Karena itu perlu secara rutin diinformasikan pada konsumen.

5. Mini Quiz. Jenis unggahan ini dimaksudkan untuk menjalin interaksi dengan konsumen. UMKM dapat memilih bentuk polling/suara atau suatu tema, Give Away, Tebak Kata, Perlombaan atau sekadar Spam Like atau komentar yang kemudian mendapat hadiah.

6. Tips dan Trik (Konten Edukasi). Konten ini berisi informasi yang dapat menambah wawasan konsumen tentang produk/jasa atau sesuai situasi dan kondisi yang sedang hangat terjadi.

Pada sesi terakhir, para mitra melakukan praktik membuat konten promosi dengan platform desain daring gratis Canva.com menggunakan telepon genggam masing-masing peserta. Salah satu kendala yang dihadapi adalah adanya peserta yang masih menggunakan telepon tipe sederhana.

Setelah praktik, tim menanyakan pada peserta mengenai ketertarikan mereka untuk berpromosi melalui media sosial setelah acara ini.

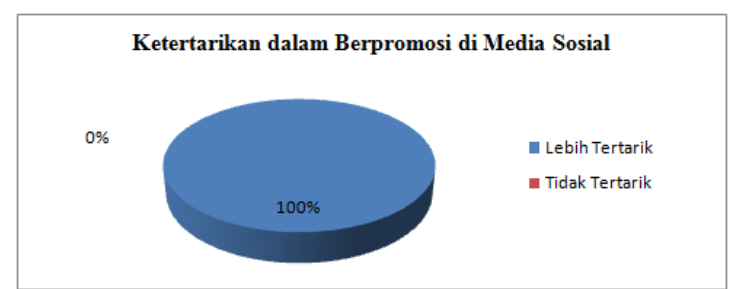

Gambar 6. Ketertarikan UMKM dalam Berpromosi di Media Sosial

Gambar 6. di atas menunjukkan $100 \%$ atau seluruh mitra tertarik berpromosi di media sosial, terutama Instagram (50\%), Facebook (25\%), dan Twitter $19 \%$. Sisanya memilih WhatsApp (6\%).

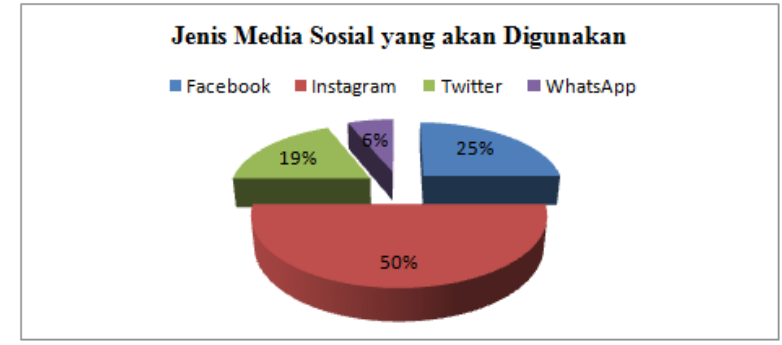

Gambar 7. Jenis Media Sosial yang Akan Digunakan UMKM



Gambar 8. Manfaat yang telah Diketahui UMKM Melakukan Promosi di Media Sosial

Gambar 8 menunjukkan bertambahnya pemahaman UMKM tentang manfaat berpromosi di media sosial. Hal ini terlihat dari ragam jawaban yang diberikan oleh para mitra. Setelah pelatihan, sebagian besar mitra mengatakan bahwa berpromosi di media sosial dapat menarik perhatian dan minat beli konsumen sekaligus menjangkau konsumen lebih luas.

Mereka juga mengakui bahwa berpromosi di media sosial dapat mengembangkan usaha, mempermudah pemasaran. Selain itu, mereka menyadari berpromosi di media sosial tidak membutuhkan biaya besar. Untuk itu mereka merasa perlu memiliki akun media sosial demi bisa memasarkan produknya.

Mengenai konten yang ingin dibuat dan diunggah di media sosial adalah sebagai berikut:

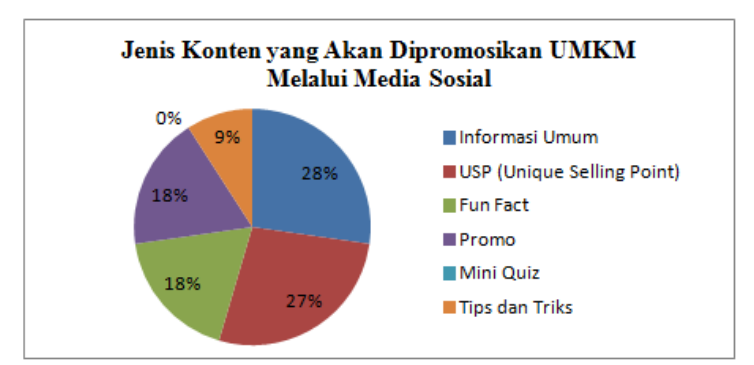

Gambar 9. Jenis Konten yang Dipromosikan UMKM melalui Media Sosial 
Gambar 9 tersebut menunjukkan 28\% mitra menghendaki informasi umum, 27\% mitra memilih USP (Unique Selling Point), 18\% konten Fun Fact dan Promo, 9\% Tips dan Triks tentang produk atau jasa mereka. Hal ini menunjukkan pemahaman mitra tentang materi pelatihan.

\section{SIMPULAN DAN SARAN}

Dari pemaparan di atas, tim menyimpulkan hal-hal sebagai berikut:

1. Hambatan yang dihadapi para pelaku UMKM mitra Masjid Al Ikhlash Jati Padang adalah belum kuatnya jiwa kewirausahaan mereka. Padahal untuk mengembangkan usaha diperlukan jiwa wirausaha yang kuat. Selain itu, juga keberanian berinovasi, memiliki kreativitas, kegigihan, dan daya saing yang kuat.

2. Meskipun sebagian pelaku UMKM sudah berpromosi secara daring, namun di antara mereka ada yang belum memahami cara berpromosi yang efektif dan berdampak.

3. Dengan pelatihan membuat konten promosi di media sosial, pemahaman peserta mengenai pentingnya berpromosi secara daring meningkat. Karena itu, pelatihanpelatihan semacam perlu terus diadakan secara rutin, agar para pelaku UMKM mitra masjid mampu bersaing pada era digital.

\section{UCAPAN TERIMA KASIH}

Program pengabdian ini merupakan skema pengabdian Program Kemitraan Masyarakat (PKM). Tim pengabdian mengucapkan terimakasih kepada Lembaga Pemberdayaan dan Pengabdian Masyarakat Universitas Muhammadiyah Prof. Dr. HAMKA (LPPM UHAMKA), Masjid Al Ikhlash Jati Padang, Jakarta, khususnya Absar Janatin, SAk, Ketua Bidang Ekonomi dan Keuangan Masjid AlIkhlas Jatipadang, Ir. Rahadi Mulyanto beserta tim Masjid Al-Ikhlas Jatipadang yang memfasilitasi dan mengkoordinasikan pelaksanaan kegiatan ini. Tak lupa kepada para pelaku UMKM mitra masjid yang secara aktif berpartisipasi dalam pelatihan ini.

\section{DAFTAR PUSTAKA}

Anarnkaporn, Angkana. (2007). Branding as a Competitive Advantage for SMEs. RU International Journal.Vol. 1 No. 1. Pp. 2536.

Hadiwinata, Khrisna, Hudriyah Mundzir, and Shohib Muslim. (2020). "Analisis Peran Media Sosial Instagram Sebagai Media Pemasaran Dan Branding Bisnis Di Era Pandemi Covid-19." Senabisma 6(2): 62-68. Jauhari Jaidan. (2010). Upaya Pengembangan Usaha Kecil dan Menengah (UKM) dengan Memanfaatkan E-Commerce. Jurnal Sistem Informasi (JSI), VOL. 2, NO. 1, April 2010. Halaman 159-168.

Magrath, V dan McCormick, H., (2013). "Marketing design elements of mobile fashion retail apps". Journal of Fashion Marketing and Management: An International Journal. Vol. 17 Issue: 1, pp.115-134.

Permatasari dan Endriastuti., (2020). "Pelatihan Pemanfaatan Media Sosial Sebagai Alat Pemasaran Bagi UMKM Di Kecamatan Kedungpring, Kabupaten Lamongan, Jawa Timur. Jurnal Layanan Masyarakat (Journal of Public Service), vol 4 no 1 Tahun 2020, halaman 91-99

Prasetijo, Tistiyanti, dan John. (2006). Perilaku Konsumen Indonesia: Andi Publisher Subanar, Harimurti. 2001. Manajemen Usaha Kecil. Yogyakarta: BPFE

Sari, Nursita. (2020). "Saat $66 \mathrm{RW}$ Zona Merah Covid-19 di Jakarta Tersisa 5, tapi Bertambah lagi jadi 27 RW'. https://megapolitan.kompas.com/read/2020/06/ 26/06320501/saat-66-rw-zona-merah-covid19-di-jakarta-tersisa-5-tapi-bertambahlagi? page $=$ all Diakses pada 6 Juni 2020 pukul: 15.50 WIB.

Undang-Undang Nomor 20 Tahun 2008 Tentang Usaha Mikro, Kecil, dan Menengah.

We are Soscial \& Hootsuite. (2020). "Digital Data Indonesia 2020" Retrieved from https://datareportal.com/reports/digital2020-indonesia. Diakses pada 6 Juni 2020 pukul: $14.00 \mathrm{WIB}$.

Wirabrata, A. (2016). Prospek Ekonomi Digital Bagi Peningkatan Pertumbuhan Ekonomi. Majalah Info Singkat Ekonomi Dan Kebijakan Publik, VIII (17P3DI), 13-16. Retrieved from www.pengkajian.dpr.go.id 